\title{
FACTORS INFLUENCING SUCCESS OF WOMEN ENTREPRENEURS IN KANYAKUMARI DISTRICT
}

\begin{tabular}{ll} 
R. Jackulin Ancy & Research Scholar \\
\hline Herald M Dhas * & Associate Professor *Corresponding Author
\end{tabular}

ABSTRACT Women Entrepreneurship is an important part of social and economic development of a country. Now women have realized their importance in the society and their participation in economic activities is also increasing. The development of the industry depends on the efficiency of the women entrepreneur. Since the nature of entrepreneur and the financial, marketing and other constraints that will restricts the development of the women entrepreneurship, the researcher has carried out the present study. As far as the present study is concerned, the investigator has proposed to collect the data required from the sample population by adopting percentage sampling technique. The researcher has targeted 150 sample respondents from which the percentage of the total in proportion to the number of members and the total targeted respondents. The Kanyakumari district comprises of four taluks and three taluks are selected for field survey. From each taluk, 50 entrepreneurs are selected as sample. 150 women entrepreneurs are identified as the sample respondents for the study by using convenience random sampling method. The industries are considered as ideal nurseries for the rapid growth and development of women entrepreneurs. The need of the hour is the growth of women entrepreneurs in the country to accelerate the process of economic growth. It is found that 'Career challenge' is the important self-motivating factor influencing success of women entrepreneurs having a mean score of 3.66 and 'Entrepreneurial opportunities' is the next important selfmotivating factor influencing success of women entrepreneurs having a mean score of 3.39 and 'Ideas for business ventures' has been ranked at the lowest among the entrepreneurs with the mean score of 2.61.

KEYWORDS : Women Entrepreneurs, Economic Development, Self-motivating factor and Entrepreneurial Opportunities

\section{INTRODUCTION}

Women Entrepreneurship is an important part of social and economic development of a country. Now women have realized their importance in the society and their participation in economic activities is also increasing. Women empowerment is must for a modern developed economy through women entrepreneurship. For ensuring empowerment of women, educational attainment and economic participation are the key constituents. Women empowerment is the term which has come to occupy an important position globally over the years. Various governments and voluntary organizations or agencies carried out seminars, workshops and conferences to show the value of women activities like arrangement of training for Women, technology development etc. Right approach for women empowerment in developing economy will be entrepreneurship among women which enhance their socio-economic status.

\section{STATEMENT OF THE PROBLEM}

Presently women entrepreneurs comprise of 10 per cent of the total entrepreneurs in India. It is also clear that this percentage is growing every year. The role of women entrepreneurs helps to solve the problems of unemployment and poverty. Development of women entrepreneurs is an essential part of human resource development. Entrepreneurship amongst women has been a recent concern. The development of women entrepreneurs is very low in India. Women have been playing a crucial role in running the family in Kanyakumari. In olden days women were married at an early age and their focus were centred around the family. They were uneducated and ignorant of the conditions prevailing in the country. The post independent period has witnessed a significant improvement in women's education in India. In Kanyakumari literacy level among the female population has gone up over the decades, a little faster than the males. As more and more women were educated, they turned up to seek employment. In course of time, they compete with men folk in education and training and staked their claim for equal jobs. Due to acute shortage of job opportunities and stiff competition prevailing more and more women have opted for entrepreneurship and set up their own ventures. Moreover, emergence of nucleus family, non availability of reliable servants and lack of proper hygienic crèches force many a woman to leave their jobs and careers and start their own business. So women will have to brave the odds and succeed. Many studies indicate that at the very point of starting a small business, women are found to face more barriers than men. Research has shown that women face a number of difficulties in establishing and maintaining business.

\section{OBJECTIVES OF THE STUDY}

1. To analyse the factors influencing success of women entrepreneurs in Kanyakumari

2. To measure the risk taking behaviour of women entrepreneurs business in Kanyakumari

\section{SAMPLING DESIGN}

As far as the present study is concerned, the investigator has proposed to collect the data required from the sample population by adopting percentage sampling technique. The researcher has targeted 150 sample respondents from which the percentage of the total in proportion to the number of members and the total targeted respondents. The Kanyakumari district comprises of four taluks and three taluks are selected for field survey. From each taluk, 50 entrepreneurs are selected as sample. 150 women entrepreneurs are identified as the sample respondents for the study by using convenience random sampling method.

\section{COLLECTION OF DATA}

The present study was based on both primary and secondary data. Well structured and pretested questionnaire was used for collecting primary data. The questionnaire was prepared by a five-point Likert scale to collect the information required for the study after an in-depth review of the previous studies related to the topic of the present study, discussions with the officials of the District Industries Centre (DIC) and experienced women entrepreneurs in Small Scale Industries. It was then judged for content validity and pre-tested on a group of conveniently selected respondents to assess its clarity and ease of completion. Based on the recommendations received, it is modified and subsequently given to the study sample for the data collection. The

\begin{tabular}{c|c|c}
\hline Submitted $: 27^{\text {th }}$ June, 2019 & Accepted $: 24^{\text {th }}$ July, 2019 & Publication : 15 ${ }^{\text {th }}$ October, 2019 \\
\hline
\end{tabular}


questionnaire focuses on motivating factors, constraints of women entrepreneurs. In the questionnaire, some questions consist of multiple items while others are single items.

Secondary data have been collected from books, journals, newspapers, periodicals, reports, internet, unpublished Ph.D theses, and unpublished records of District Industries Centre, Kanyakumari. The data from directorate of industries and commerce, Chennai and Tamil Nadu Industrial Investment Corporation Ltd. have also been collected in their websites.

\section{PERIOD OF STUDY}

The study was conducted in the year $2018-19$. The primary data were collected from the women entrepreneurs during the period from December 2018 to March 2019. The data related to the developments of women entrepreneurs were obtained from the date of starting their enterprises.

\section{DATA PROCESSING}

After the completion of data collection, filled up questionnaires were edited properly to make them ready for coding. Questionnaires were coded numerically in different numbers from serial numbers to enable the researcher to enter the data systematically and efficiently and to maintain no missing questionnaires. The processing of data was done through computer technology packages of SPSS (Statistical Package for Social Science) version 21. Data screening was performed through the frequency to assure check for any error.

\section{LIMITATIONS OF THE STUDY}

1. The study covered only Kanyakumari district. Hence the findings and conclusions of the study are entirely applicable to this district only and it may not hold good for other areas.

2. The study was based on the perceptions of the women entrepreneurs, whose attitudes may change with the change of times. Therefore, the responses reflect only their contemporary views on the prevailing conditions.

3. Present study covered only the women entrepreneurs engaged in manufacturing and service sector under Small Scale Industries.

\section{ANALYSIS AND INTERPRETATION}

Self-motivating factors influencing success of women entrepreneurs

Self-motivating factors influencing success of women entrepreneurs namely career challenge, personal skills and competencies, role model, self identity, entrepreneurial opportunities and ideas for business ventures. The following table shows that self-motivating factors influencing success of women entrepreneurs.

Table 1 Self-motivating factors influencing success of women entrepreneurs

\begin{tabular}{|l|l|c|c|c|c|c|c|c|}
\hline $\begin{array}{l}\text { Sl. } \\
\text { No }\end{array}$ & $\begin{array}{l}\text { Self-motivating } \\
\text { factors }\end{array}$ & SA & A & NO & DA & SDA & $\begin{array}{l}\text { Mean } \\
\text { Score }\end{array}$ & Rank \\
\hline 1. & Career challenge & 42 & 62 & 10 & 22 & 14 & 3.66 & I \\
\hline 2. & $\begin{array}{l}\text { Personal skills } \\
\text { and competencies }\end{array}$ & 25 & 34 & 22 & 39 & 30 & 2.88 & IV \\
\hline 3. & Role model & 29 & 45 & 17 & 30 & 29 & 3.12 & III \\
\hline 4. & Self identity & 20 & 35 & 15 & 38 & 42 & 2.69 & V \\
\hline 5. & $\begin{array}{l}\text { Entrepreneurial } \\
\text { opportunities }\end{array}$ & 40 & 55 & 7 & 20 & 28 & 3.39 & II \\
\hline 6. & $\begin{array}{l}\text { Ideas for business } \\
\text { ventures }\end{array}$ & 16 & 25 & 32 & 37 & 40 & 2.61 & VI \\
\hline
\end{tabular}

Source: Primary data

It is understood from the above table that 'Career challenge' is the important self-motivating factor influencing success of women entrepreneurs having a mean score of 3.66 and
'Entrepreneurial opportunities' is the next important selfmotivating factor influencing success of women entrepreneurs having a mean score of 3.39 and 'Ideas for business ventures' has been ranked at the lowest among the entrepreneurs with the mean score of 2.61 .

Economic factors influencing success of women entrepreneurs

Economic factors influencing success of women entrepreneurs namely economic independence, financial independence, self-employment, poor economic condition of the family, availability of land and building and rescue from unemployment. The following table shows that economic factors influencing success of women entrepreneurs.

Table 2 Economic factors influencing success of women entrepreneurs

\begin{tabular}{|c|l|c|c|c|c|c|c|c|}
\hline $\begin{array}{c}\text { Sl. } \\
\text { No }\end{array}$ & Economic factors & SA & $\bar{A}$ & NO & DA & SDA & $\begin{array}{l}\text { Mean } \\
\text { Score }\end{array}$ & Rank \\
\hline 1. & $\begin{array}{l}\text { Economic } \\
\text { independence }\end{array}$ & 30 & 47 & 23 & 28 & 22 & 3.23 & V \\
\hline 2. & $\begin{array}{l}\text { Financial } \\
\text { Independence }\end{array}$ & 30 & 52 & 19 & 20 & 27 & 3.25 & IV \\
\hline 3. & Self-employment & 37 & 62 & 13 & 19 & 17 & 3.54 & II \\
\hline 4. & $\begin{array}{l}\text { Poor economic } \\
\text { condition of the } \\
\text { family }\end{array}$ & 34 & 54 & 14 & 15 & 33 & 3.28 & III \\
\hline 5. & $\begin{array}{l}\text { Availability of land } \\
\text { and building }\end{array}$ & 21 & 37 & 10 & 32 & 50 & 2.65 & VI \\
\hline 6. & $\begin{array}{l}\text { Rescue from } \\
\text { unemployment }\end{array}$ & 45 & 70 & 5 & 23 & 7 & 3.80 & I \\
\hline
\end{tabular}

\section{Source: Primary data}

The above table shows that 'Rescue from unemployment' is the important economic factor influencing success of women entrepreneurs having mean score of 3.80 and 'selfemployment' is the next important economic influencing success of women entrepreneurs having mean score of 3.54 and 'Availability of land and building' has been ranked at the lowest among the entrepreneurs with the mean score of 2.65.

Technical factors influencing success of women entrepreneurs

Technical factors are influencing success of women entrepreneurs namely knowledge of business, innovations, hereditary business skills, new technologies and new products in the market. The following table shows the technical factors influencing success of women entrepreneurs.

Table 3 Technical factors influencing success of women entrepreneurs

\begin{tabular}{|c|l|c|c|c|c|c|c|c|}
\hline $\begin{array}{c}\text { Sl. } \\
\text { No }\end{array}$ & Technical factors & SA & $\mathbf{A}$ & NO & DA & SDA & $\begin{array}{l}\text { Mean } \\
\text { Score }\end{array}$ & Rank \\
\hline l. & Business knowledge & 39 & 68 & 10 & 14 & 19 & 3.63 & I \\
\hline 2. & Innovations & 32 & 45 & 22 & 26 & 25 & 3.22 & IV \\
\hline 3. & $\begin{array}{l}\text { Hereditary Business } \\
\text { skills }\end{array}$ & 35 & 40 & 32 & 20 & 23 & 3.29 & III \\
\hline 4. & New technologies & 37 & 62 & 12 & 17 & 22 & 3.52 & II \\
\hline 5. & $\begin{array}{l}\text { New products in the } \\
\text { market }\end{array}$ & 26 & 42 & 19 & 34 & 29 & 3.01 & V \\
\hline
\end{tabular}

Source: Primary data

It is understood from the above table that 'Business knowledge' is the important technical factor influencing success of women entrepreneurs having a mean score of 3.63 and 'New technologies' is the next important technical factor influencing success of women entrepreneurs having a mean score of 3.52 and 'New products in the market' have been 
ranked at the lowest among the entrepreneurs with the mean score of 3.01 .

\section{Social factors influencing success of women entrepreneurs} Social factors influencing success of women entrepreneurs namely social status, desire for social work, want to change the negative attitude of the society and the want to be unique. The following table shows the social factors influencing success of women entrepreneurs.

Table 4 Social factors influencing success of women entrepreneurs

\begin{tabular}{|c|l|c|c|c|c|c|c|c|}
\hline $\begin{array}{c}\text { Sl. } \\
\text { No }\end{array}$ & \multicolumn{1}{|c|}{ Social factors } & SA & A & NO & DA & SDA & $\begin{array}{c}\text { Mean } \\
\text { Score }\end{array}$ & Rank \\
\hline 1. & Social status & 42 & 63 & 7 & 26 & 12 & 3.66 & I \\
\hline 2. & Desire for social work & 35 & 45 & 17 & 31 & 22 & 3.26 & IV \\
\hline 3. & $\begin{array}{l}\text { Want to change the } \\
\text { negative attitude of } \\
\text { the society }\end{array}$ & 40 & 55 & 15 & 25 & 15 & 3.54 & III \\
\hline 4. & Want to be unique & 41 & 60 & 11 & 29 & 9 & 3.65 & II \\
\hline
\end{tabular}

Source: Primary data

The above table shows that 'Social status' is the important social factor influencing success of women entrepreneurs having a mean score of 3.66 and the 'Want to be unique' is the next important social factor influencing success of women entrepreneurs having mean score of 3.65 and 'Desire for social work' has been ranked at the lowest among the entrepreneurs with the mean score of 3.26 .

Family background factors influencing success of women entrepreneurs

Family background factors are influencing success of women entrepreneurs namely motivation from family, family innovativeness, ambition of family and financial commitments of the family. The following table shows the family background factors influencing success of women entrepreneurs.

Table 5 Family background factors influencing success of women entrepreneurs

\begin{tabular}{|c|l|c|c|c|c|c|c|c|}
\hline $\begin{array}{c}\text { Sl. } \\
\text { No }\end{array}$ & $\begin{array}{l}\text { Family background } \\
\text { factors }\end{array}$ & SA & $\mathbf{A}$ & NO & DA & SDA & $\begin{array}{c}\text { Mean } \\
\text { Score }\end{array}$ & Rank \\
\hline 1. & $\begin{array}{l}\text { Motivation from } \\
\text { family }\end{array}$ & 44 & 61 & 10 & 17 & 18 & 3.62 & II \\
\hline 2. & $\begin{array}{l}\text { Family } \\
\text { innovativeness }\end{array}$ & 38 & 57 & 6 & 16 & 33 & 3.37 & III \\
\hline 3. & Ambition of family & 30 & 45 & 18 & 25 & 32 & 3.10 & IV \\
\hline 4. & $\begin{array}{l}\text { Financial } \\
\text { commitments of the } \\
\text { family }\end{array}$ & 46 & 70 & 5 & 18 & 11 & 3.81 & I \\
\hline
\end{tabular}

Source: Primary data

It is understood from the above table that 'Financial commitments of the family' is the important family background factor influencing success of women entrepreneurs having a mean score of 3.81 and 'Motivation from family is the next important family background factor influencing success of women entrepreneurs having a mean score of 3.62 and 'Ambition of family' has been ranked at the lowest among the entrepreneurs with the mean score of 3.10 .

Risk taking behaviour among different age group of Women Entrepreneurs

Women entrepreneurs of different age groups have different risk taking behaviour. In order to find out the significant difference in risk taking behaviour among different age group of women entrepreneurs in Kanyakumari district, 'ANOVA' test is attempted with the null hypothesis as, "There is no significant difference in risk taking behaviour among different age group of women entrepreneurs in Kanyakumari district". The result of 'ANOVA' test for risk taking behaviour among different age group of women entrepreneurs is presented in Table 6.

Table 6 Risk Taking Behaviour among different Age group of Women entrepreneurs

\begin{tabular}{|c|c|c|c|c|c|}
\hline \multirow{2}{*}{$\begin{array}{l}\text { Risk Taking } \\
\text { Behaviour }\end{array}$} & \multicolumn{4}{|c|}{ Age Group (Mean Score) } & \multirow{2}{*}{$\begin{array}{c}\text { F- } \\
\text { Statistics }\end{array}$} \\
\hline & $\begin{array}{c}\text { Up to } \\
30 \\
\text { years }\end{array}$ & $\begin{array}{l}30-40 \\
\text { years }\end{array}$ & \begin{tabular}{|c|}
$40-50$ \\
years \\
\end{tabular} & $\begin{array}{c}\text { Above } \\
50 \\
\text { years }\end{array}$ & \\
\hline Self-confidence & 4.0000 & 4.1188 & 4.0955 & 4.2206 & 1.456 \\
\hline $\begin{array}{l}\text { Communication } \\
\text { skills }\end{array}$ & 3.5577 & 3.9625 & 3.5955 & 4.0147 & $4.468^{*}$ \\
\hline $\begin{array}{l}\text { Keeping oneself } \\
\text { mentally and } \\
\text { physically busy }\end{array}$ & 3.8269 & 3.9875 & 4.0545 & 3.9412 & 1.841 \\
\hline $\begin{array}{l}\text { Skillful hands } \\
\text { easily available }\end{array}$ & 4.1962 & 4.0375 & 4.0091 & 4.0441 & 1.117 \\
\hline $\begin{array}{l}\text { Resource sharing } \\
\text { ability }\end{array}$ & 3.8077 & 3.9063 & 3.9818 & 3.8088 & 1.639 \\
\hline $\begin{array}{l}\text { Able to manage } \\
\text { business }\end{array}$ & 3.9231 & 4.1625 & 4.0091 & 4.1765 & 1.631 \\
\hline $\begin{array}{l}\text { Able to earn high } \\
\text { profit }\end{array}$ & 3.8654 & 3.8813 & 4.1545 & 3.9412 & 1.074 \\
\hline Able to handle risk & 4.1731 & 4.1938 & 4.0909 & 4.2500 & 1.030 \\
\hline $\begin{array}{l}\text { Able to take } \\
\text { decision by own }\end{array}$ & 4.3654 & 3.9625 & 3.9455 & 4.0480 & $2.306^{*}$ \\
\hline $\begin{array}{l}\text { Able to accept } \\
\text { challenges }\end{array}$ & 3.7885 & 3.8938 & 4.0091 & 3.8235 & 1.078 \\
\hline $\begin{array}{l}\text { Gained adequate } \\
\text { skills }\end{array}$ & 4.1875 & 4.1159 & 4.1561 & 4.1538 & 1.128 \\
\hline Able to work hard & 4.1597 & 4.1572 & 3.8098 & 3.9231 & $4.220^{*}$ \\
\hline $\begin{array}{l}\text { Efficient material } \\
\text { handling }\end{array}$ & 4.0000 & 3.9855 & 3.8585 & 3.4615 & 1.454 \\
\hline
\end{tabular}

Source: Primary data

${ }^{*}$-Significant at five per cent level

Table 6 shows the mean score of risk taking behaviour among different age group of women entrepreneurs along with its respective ' $F$ ' statistics. The important risk taking behaviour among the women entrepreneurs who are in the age group of up to 30 years are skillful hands easily available and gained adequate skills and their respective mean scores are 4.1962 and 4.1875. Among the women entrepreneurs who are in the age group of 30 to 40 years, the important risk taking behaviour are able to handle risk and able to manage business and their respective mean scores are 4.1938 and 4.1625. The important risk taking behaviour among the women entrepreneurs who are in the age group of 40 to 50 years are gained adequate skills and able to earn high profit and their respective mean scores are 4.1561 and 4.1545. Among the women entrepreneurs who are in the age group of above 50 years, the important risk taking behaviour are able to handle risk and self-confidence and their respective mean scores are 4.2500 and 4.2206. Regarding the risk taking behaviour, the significant difference among the different age group of women entrepreneurs, are identified in the case of communication skills, able to take decision by own and able to work hard since the respective ' $F$ ' statistics are significant at 5 per cent level, the null hypothesis is rejected.

\section{SUGGESTIONS}

- Women entrepreneurs should be encouraged to start their entrepreneurs as joint stock companies rather than as a sole trade and partnership concerns to avail the advantage of large scale operation.

- Improper location and inadequate infrastructure facilities 
are the hurdles in the way of development of women entrepreneurship. Hence, separate industrial estates may be set up exclusively for women entrepreneurs to reduce the initial investment and to create a special environment.

- For managing stress, enhancing leadership qualities, workforce management etc. women entrepreneurs need to be trained, as many of them are not having any professional/managerial education.

- Most of the women entrepreneurs are of the opinion that because of lack of training, they are not able to survive in the market. Hence, the government should conduct frequent training programmes with regard to new production techniques, sales techniques etc. This training should be made compulsory for women entrepreneurs.

\section{CONCLUSION}

The development of the industry depends on the efficiency of the women entrepreneur. Since the nature of entrepreneur and the financial, marketing and other constraints that will restricts the development of the women entrepreneurship, the researcher has carried out the present study.

The industries are considered as ideal nurseries for the rapid growth and development of women entrepreneurs. The need of the hour is the growth of women entrepreneurs in the country to accelerate the process of economic growth.

The present study will help the planners and the decision makers who are involved in the development of women entrepreneurs to review the existing policies and to make suitable suggestions to amend the provisions of the act which governs the industries. Based on the experience of the researcher the following important issues have been identified for an in depth study. The researcher will feel amply rewarded if the present study helps to undertake similar studies in the areas suggested below.

\section{REFERENCES}

1. Rathna, Badrinath and Siva Sundaram Anushan (2016). A Study on Entrepreneurial Motivation and Challenges faced by Women Entrepreneurs in Thanjavur District. Indian Journal of Science and Technology, Vol.9, No.27, pp.1-10.

2. Shapna Yasmin and Prathiba (2016). Motivational Factors of Women Entrepreneurs. International Contemporary Research Journal in Management and Social Science, Vol.2 Issue.2, pp.133-137.

3. Fathema Farjana Hani (2015). Entrepreneurial Motivation and Challenges: A Study on Women Entrepreneurs in Sylhet City. Global Disclosure of Economics and Business, Vol.4, No.2, pp.111-122.

4. Natanya Meyer and Johann Landsberg (2015). Motivational Factors Influencing Women's Entrepreneurship: A Case Study of Female Entrepreneurship in South Africa. World Academy of Science, Engineering and Technology, International Journal of Social, Behavioral, Educational, Economic, Business and Industrial Engineering, Vol:9, No:11, pp.3798-3803. 